\title{
Farklı Bir Perspektiften Terörizm
}

*

\begin{abstract}
$\underline{\text { Hüseyin Arslan }}^{*}$
* Yrd. Doç. Dr., Polis Akademisi Başkanlığı, Güvenlik Bilimleri Enstitüsü, Ankara/ Türkiye
\end{abstract}

E-posta: harslan341@gmail.com

\section{Öz}

Terör meselesi, güvenlik açısından Türkiye'nin karşılaştığı en önemli sorunlardan biridir. Bu sorunun çözümü için Ak Parti iktidarları tarafından pek çok politika geliştirilmiştir. Bu çalışmada, Türkiye'nin güvenliğini bu kadar yakından ilgilendiren terör meselesinin çözümünde Said Nursi'nin rol modelliği üzerinde durulacaktır. Yol haritasında üç ana madde bulunmaktadır. Birincisi, Said Nursi'nin hayatını adadı̆̆g Medresetü'z-Zehra projesinin çözüm süreci açısından önemini irdelemektir. İkinci maddede Said Nursi'nin, Türk-Kürt kardeşliğine verdiği değer ve önem ele alınacaktır. Son olarak, Cumhurbaşkanı Recep Tayyip Erdoğan'ın 3 Ekim 2009'da Ak Parti Üçüncü Olağan Kongresi'nde Said Nursi'nin ismini zikrederek yaptığı tarihi konuşması çözüm süreci bağlamında tahlil edilmeye çalışlacaktır.

Key Words: Terör Meselesi, Said Nursi, Medresetü'z-Zehra, Türk-Kürt kardeşliği. 


\title{
A Different Perspective on Terrorism
}

\begin{abstract}
Terrorissue is one of the most important issues challenging the Turkish security. To tackle the issue, the AKP governments are among the ones who have developed numerous political measures. The aim of this essay is to analyze Said Nursi's role model in solving the issue that concerns most the security of Turkish state. Here there are three main steps to follow. Firstly, it is the aim of this essay to scrutinize the project 'Madrasa al-Zahra', which Said Nursi dedicated his whole life to it to solve the issue. Secondly, the essay will discuss how he attached great importance and value to Turkish-Kurdish brotherhood. And finally, President Recep Tayyip Erdoğan's historical speech will be analyzed. In his speech he made in the Third Ordinary Congress of AKP in October 2009, the president mentioned the name of Said Nursi in relation with the issue.
\end{abstract}

Anahtar Kelimeler: Terror issue, Said Nursi, Madrasa al-Zahra, Turkish-Kurdish brotherhood. 


\section{Giriş}

Türkiye Cumhuriyeti, 29 Ekim 1923'tenbugüne kadar, güvenlik açısından pek çok iç ve diş tehditle karşılaşmıştır. Bu tehditler Türkiye'ye,demokratikleşme,insan hak ve özgürlükleri, ekonomik gelişme, siyasal istikrara kavuşma, modernleşme ve küresel bir aktör olma yolunda telafisi olmayan çok ağır bedeller ödetmiştir.

Bu bağlamda jeopolitik önemi herkesçe bilinen Türkiye'nin güvenliğini tehdit eden en önemli sorunlardan birisi PKK terör örgütü ve türevleri tarafından özellikle Güney Doğu ve Doğu Anadolu bölgelerinde sürdürülen kanlı mücadeledir. Sözde siyasal, kültürel, temel haklar ve özgürlükler bağlamında Kürtlere yeni bir statü sağlanması hedefiyle 1980'li yılların ortalarında PKK tarafından başlatılan ve 30 yılı aşkın bir süredir devam eden çatışmalar sonucunda onbinlerle ifade edilen can kaybının yanı sıra büyük bir ekonomik kayıp da yaşanmıştır.

Terörle etkin bir şekilde mücadele konusunda geçmiş siyasi iktidarlar tarafından bazı adımlar atılmış, fakat çeşitli sebepler yüzündennihai sonuç alınamamıştır.Bu bağlamda 1999 genel seçimlerinden sonra 57. Cumhuriyet Hükümetini kuran DSP-MHP ve ANAP tarafından hazırlanan koalisyon hükümeti protokolünde, terörle etkin bir şekilde mücadele edileceği belirtilmiştir. Ayrıca Güneydoğu ve Doğu Anadolu bölgelerinin kalkınması için sosyal ve ekonomik tedbirlerle ilgili gerekli politikaların hızlı bir şekilde uygulanacağına vurgu yapılmıştır (TBMM). Ancak geçmişte atılan adımların çoğundameseleye salt bir güvenlik sorunu olarakbakılmış, kalıcı çözüm yerine geçici tedbirler düşünülmüştür.Bu yüzden geniş bir perspektifle insan hak ve özgürlüklerini önceleyen, demokratikleşme adına, sosyal, siyasal ve ekonomik alanlarda toplumun önünü açan tedbirlerin alınması gecikmiştir. Dolayısıyla terör sorununun çözümünde kaybedilen vakit, Türkiye'nin böylesine önemli bir güvenlik meselesinden en az zararla çıkma ihtimalinihep ötelemiştir.

Ak Parti hükümetleri tarafından bu sorunun çözümü için seleflerine göre daha ciddi adımlar atılmış ve milli birlik ve kardeşliği pekiştirmek üzere kamuoyunda "çözüm süreci" olarak bilinen süreç dâhilinde demokratikleşme adına sosyal, siyasal ve ekonomik alanlarda bir hayli düzen- 
leme yapılmıştır. Silahların sustuğu ve siyasetin ön plana çıtı̆̆ bu süreç, belirlenen yol haritası kapsamında ilerlerken bir anda20 Temmuz 2015 tarihinde Suruç saldırısıyla yüzleşmek zorunda kalmıştır. Suruç'ta bombalı intihar saldırısıyla 30'u aşkın vatandaşımızın katledilmesinin şoku atlatılmadan, PKK tarafından 22 Temmuz 2015'te Ceylanpınar'da kaldıkları evde uyuyan iki polis şehit edilmiştir. Bu şekilde tetiklenen terör saldırıları sonucunda çözüm süreci buzdolabına kaldırılmış ve dolayısıyla süreç tekrar bir belirsizlik girdabına sürüklenmiştir.

Yaşanan gelişmelerden hareketle bu çalışmadaki amaç;terör meselesinin hangi saiklerle ve ne amaçlarla başladığı, arka planında yatan temel sebeplerin ne olduğu ya da ideolojik olarak dayandığı ana felsefenin tahlil edilmesi, Türklerle Kürtlerin bir arada yaşama tecrübesinin terör olaylarıyla ayrıştırılma, kin ve nefrete dönüştürülme çabalarının irdelenmesi değildir. Ana hedef, bu meselenin kalıcı olarak çözümü için iktidar partisi tarafından milli birlik ve kardeşlik projesi kapsamında "çözüm süreci"adıyla yürütülen ve Türkiye'nin daha da demokratikleşmesi bağlamında gerçekleştirilen siyasi, sosyal ve ekonomik reformlar da gözönünde tutularak, hayatını Türk-Kürt kardeşliğini önemseyerek sıkıntılarla tüketen Said Nursi perspektifinden bu sorunabakmaya çalışmak ve onu bir rol model olarak sunmaktır.

Şerif Mardin gibi dünya çapındaki bir bilim adamının Said Nursi ile ilgili yazdığı bir kitap yüzünden ilim çevrelerinden aforoz edildiği gerçeği hafızalardaki tazeliğini korurken yakın geçmişe kadar bir tabu olarak görülen Said Nursi gibi bir dini cemaat liderini bir makalenin sınırları dâhilinde bir rol model olarak sunmak kolay değildir.Ayrıca bu konuyla ilgili Said Nursi'nin kendi eserleri ve bu eserlerden hareketle oluşturulan özgün çalışmalar dışında literatürde pek fazla kaynağın olmadığının belirtilmesinde fayda vardır.

Yol haritasında üç ana madde bulunmaktadır. Bunlardan birincisi, Said Nursi'nin gerçekleştirmek için hayatını adadığı Medresetü'z-Zehra projesinin süreç açısından önemini irdelemektir.İkinci maddede Said Nursi'nin, dönemindeki Kürt isyanlarını önlemek için yaptığı girişimler ve özellikle isyanına destek istemek üzere gönderdiği adamları vasıtasıyla Şeyh Sait'e Türk-Kürt kardeşliğini ön plana çıkartarak verdiği tarihi cevap bulunmaktadır. Son olarak da Cumhurbaşkanı Recep Tayyip Erdoğan'ın 
başbakanlığı döneminde 3 Ekim 2009'da Ak Parti'nin düzenlediği 3. Olağan Kongresi'nde Ahmed-i Hani (Özervarl1,1997;31-32) ${ }^{1}$ ve Said Nursi isimlerini zikrederek yaptığı tarihi konuşma üzerinden çözüm sürecini tahlil etmeye çalışmaktır.

Said Nursi'nin 23 Mart 1960 tarihinde vefat ettiği, çözüm sürecinin ise onun vefatından yıllar sonra başladığı göz önüne alındığında meseleyle Said Nursi'nin adının ilişkilendirilmesinin kafalarda soru işaretleri yaratacağı aşikârdır. Çalışmanın amaçlarından birisi de bu soru işaretlerini izale etmektir.

Said Nursi'nin Medresetü'z-Zehra projesinin süreç açısından önemi irdelenilmeden önce, meselenin kalıcı çözümü için başlatılan süreçle ilgili kısa bir bilgi verilmesi ve bu konuda Ak Parti iktidarlarınca gerçekleştirilen icraatlara göz atılması yerinde olacaktır.

\section{Çözüm Sürecine Kısa Bir Bakış}

Türkiye'yi uzun yıllardır uğraştıran "Terör Meselesi"nin kalıcı çözümü için Ak Parti iktidarları döneminde başlatılan süreç, "Çözüm Süreci" ya da "Barış Süreci" adıyla hafızalara kazınmıştır. Sürecin temel amacı, silah ve şiddetin sebep olduğu, kan ve gözyaşının durmadığı bir çatışma halinden, insanların güven içinde yaşayabileceği, diyaloğun ve hoşgörünün ön plâna çıktığı bir toplumsal zemin yaratarak huzur ve barış içinde Türkiye'ningeleceğini inşa etmek olarak lanse edilmektedir.

Cumhurbaşkanı Recep Tayyip Erdoğan, bu amaçla yürütülen çözüm/barış sürecinin mimarılarakgösterilmektedir.Bu yüzden Erdoğan'ın başbakanlığı dâhilsürecin başından itibaren takındığı tavır, siyaseten hareket tarzı, eylemleri ve söylemleriher zaman dikkatle takip edilmekte ve pozisyonlar buna göre alınmaktadır.Nitekim PKK'nın süreci olumsuzlama anlaminda de facto bir durum yaratma amaciyla 22 Temmuz 2015'te Ceylanpınar'da kaldıkları evde uyuyan iki polisi şehit etmesiyle (http://www.sabah.com.tr/gundem/2015/07/22/2-polis-sehit-edildi) başla-

\footnotetext{
${ }^{1}$ Özervarlı'nın verdiği bilgilere göre, Ahmed-i Hânî tasavvufla ilgilenmesinin yanı sıra dönemini iyi etüt etmiş, halkı iyi gözlemlemiş, insanların sahipsizliğinden yakınmış, döneminin sosyal ve siyasal sıkıntıları üzerinde durmuş ve bu meselelerin sosyal dayanışma ve bilgilenme ile aşılabileceğini eserlerinde işlemiş bir şahsiyettir.
} 
yan operasyonlar sonucu çözüm sürecinin 11 Ağustos 2015 tarihi itibarıyla buzdolabına kaldırıldığını da herkes Cumhurbaşkanı Erdoğan'dan öğrenmiştir (http/www.turkiyegazetesi.com.tr/politika/296110.aspx).

7 Haziran 2015'te yapılan ve hiçbir partinin tek başına iktidar olmak için yeterli oyu alamadığı genel seçimlerden sonra oluşan siyasi istikrarsızlık ortamı, PKK ve terör yandaşları için münbit bir zemin yaratmış ve terör eylemleri tırmanmıştır. Bu gelişmelerden sonra Cumhurbaşkanı Erdoğan ve iktidardaki Ak Partihükümeti, sürecin devamı için tek şart olarak PKK'nın silahları bırakması ve Türkiye sınırları dâhilindeki bütün teröristlerin sınır dışına çıkması gerektiğini deklare etmişlerdir.Aksi taktirde bu mücadelenin kararlılıkla sürdürüleceğinin altını çizmişlerdir. 1 Kasım 2015'te tekrarlanan genel seçimlerden sonra Ak Parti'nin tek başına iktidar olmasını sağlayansiyasi tablo,7 Hazirandan sonra oluşan kaotik havayı bir nebze dağıtmıştır. Ak Parti, milli iradenin kendisine verdiği siyasi misyon gereği, terör meselesinin çözümü için yeniden alternatif haline gelmiş ve siyaseten bu yükü omuzlamakla karşı karşıya kalmıştır.Dolayısıyla bu meselenin çözümündeki başarı ya da başarısızlık Ak Parti'nin hanesine yazılacaktır.

Çözüm süreci kapsamında yürütülen politikaların belli başlı kilometre taşları bulunmaktadır. Bunlar meselenin ne aşamalardan geçtiğini ve ne derece sahiplenildiğinin izlerini taşımaktadır. Bu açıdan Cumhurbaşkanı Erdoğan'ın başbakanken Diyarbakır'da yaptığı ve 12 Ağustos 2005 tarihli gazetelerde yer alan tarihî konuşmasındaki söylemleri, meselenin çözümüne verdiği değerin ipuçlarını barındırmaktaydı. Erdoğan bu konuşmasının bir bölümünde, geçmişte yaşanan hataları yok saymanın büyük devletlere yakışmadığını, Kürt sorununun kendi sorunu olduğunu, bunu da tek bayrak, tek millet adına çözeceğini beyan etmiş ve: "Türkiye ne kadar İstanbul'sa o kadar da Diyarbakır'dır." ifadelerini kullanmıştı. Bu söylemler onun süreci bilinçli bir şekilde sahiplendiğinin ve bu konuda yaptığı açılamaların ise belli bir akıl muhasebesinden geçtiğini göstermektedir. Erdoğan'ın, sürecin başından beri çeşitli platformlarda yaptı̆̆ı konuşmalarda, bu ve bunun gibi pek çok açıklamasında sergilediği tavır, bu meselenin kalıcı çözümü için kendisini ortaya koyduğunu belirtmesi, o zaman yürüyen müzakerelerin başarıyla sonuçlanabilmesinin en önemli garantilerinden biriydi. 
Hafızaları tazelemek babında olmak üzere; Erdoğan'ın Diyarbakır'da yaptığı bu tarihi konuşmanın bir benzerini, 16 Aralık 1999'da Diyarbakır'a DSP-MHP ve ANAP'tan oluşan üçlü koalisyon hükümetinin Başbakan Yardımcısı olarak giden ANAP Genel Başkanı Mesut Yılmaz'ında yaptığını hatırlatmak gerekir. AB'ye giden yolun Diyarbakır'dan geçtiğini belirten Y1lmaz konuşmasında şunları söylemişti: "Toplum, bir vücut gibidir. Nasıl ele batan bir diken ele değil, tüm vücuda acı ve zarar verirse, toplumumuzun bir kesimine isabet eden sıkıntı da herkese acı ve zarar verir. Güneydoğu'daki sıkıntılar tüm insanlarımıza acılar vermiştir. Hiçbir sorun gibi ayrılıkçı terör meselesinin de sihirli bir çözümü yoktur. Bu sorunun kökten ve bir anda çözüldü̈̆̈̈ hiçbir ülke de yoktur. Demokrasi Türk'ün de, Kürt'ün de hakkıdır. Hak ve hürriyetler Sünni'nin de Alevi'nin de hakkıdır. Zenginlik doğudakinin de, batıdakinin de, kuzeydekinin de, güneydekinin de hakkıdır." (Milliyet Gazetesi, 17 Aralık 1999). Mesut Yılmaz'ın o zaman yaptı̆̆ bu tespitlerin günümüzde de hâlâ geçerliliğini koruduğunu belirtmek yerinde olacaktır.

Geçmişte yaşanan şiddet sarmalından beslenen, siyasi ve ekonomik geleceklerini terörün devamında görençevrelerin sebep olduğu çeşitli provakatif eylemler yüzünden çözüm süreci zaman zaman sıkıntıya düşürülmüştür. Çözüm sürecini inkıtaa uğratan en kanlı provakatif eylemlerin başında Kobani meselesi üzerinden siyasal bir partinin çağrısıyla 6-7-8 Ekim 2014 tarihinde yaşanan ve yaklaşık 50'yi aşkın vatandaşımızın ölmesiyle sonuçlanan toplumsal olaylar gelmektedir. Bu yüzden Ak Parti yönetimleri yakalanan bu tarihî fırsatın kaçmasını önlemek adına yeni stratejik yol haritaları ortaya koymuş ve paradigma değişikliğine gitmiştir.

Özetlemek gerekirse, çözüm süreci adına Ak Parti'nin strateji olarak ortaya koyduğu ve uyguladığı pek çok plan bulunmaktadır. Bunlar içinde ilk önce zikredilmesi gereken, Ak Parti'nin parti programının temel haklar ve siyasi ilkeler ana başlığı altında bulunan Doğu ve Güneydoğu alt başlığında dile getirilen hususlardır. Ak Parti'nin parti programının temel haklar ve siyasi ilkeler ana başlığı altında bulunan Doğu ve Güneydoğu alt başlı̆̆ının ilk paragrafı şöyledir:"Kimimizin Güney Doğu, kimimizin terör sorunu dediğimiz olay, maalesef Türkiye'nin bir gerçeğidir. Partimiz bu sorunun toplum hayatımızda neden olduğu olumsuzluklarm bilinciyle, bölge halkının mutluluğunu, refahın, hak ve özgürlüklerini gözeten, Türkiye'nin bütünlüğ̈̈ ve 
üniter devlet yapısıyla birlikte bölgeyi tehdit eden terörün önlenmesinde zaaf yaratmayacak bir şekilde; kalıcl, tüm toplumun duyarlılıklarına saygılı, etkili ve sorunları kökünden çözmeye yönelik bir politika izleyecektir." (http://www.akparti.org.tr/site/akparti/parti-programi\#bolum).

Toplumsal hafızada en fazla yer edinenler arasında yer alan icraatlardan birisi, demokratik açlımın devamı kabul edilen ve 2009 yılında başlatılan "Milli Birlik ve Kardeşlik Projesi"dir. Ak Parti bu projeyi "Soruları ve Cevaplarıyla Demokratik Açllım Süreci Milli Birlik ve Kardeşlik Projesi" başlığı altında bir broşür halinde Ocak 2010 yılında Tanıtım ve Medya Başkanlığı'na bastırmıştır. Başbakan ve Ak Parti Genel Başkanı R. Tayyip Erdoğan imzalı sunuş yazısından sonra 30 soru ve cevabının yer aldığı broşür metni toplamda 133 sayfadır. Broşür metnine bakıldığında, süreçle ilgili hemen hemen akla gelebilecek bütün sorular sorulmuştur. Sorulan bu sorulara da Türkiye'nin üniter yapısına halel getirilmeden, demokratik hukuk devleti olmanın gerektirdiği kapsamlı bir bakış açısıyla, kişi hak ve özgürlüklerinin ön plana çıkarıldı̆̆ı̆, kimsenin dinî inancı, etnik yapısı ve siyasi görüşüne bakılmaksızın ve "ötekileştirilmeden" kabul gördüğünü içeren doyurucu cevaplar verildiği görülmektedir.

Ak Parti'nin çözüm süreciyle ilgili yaptığı icraatlardan bir diğeri 2013 yılı çözüm süreci faaliyetleri kapsamında oluşturulan "Toplumsal Barış Yollarının Araştırılması ve Çözüm Sürecinin Değerlendirilmesi Amacıyla Kurulan Meclis Araştırma Komisyonu"dur.

Bu komisyon, 24. yasama döneminde Ak Parti Kırıkkale Milletvekili Ramazan Can ve 20 milletvekilinin verdiği 10/576 sayılı, Ak Parti Kahramanmaraş Milletvekili Mahir Ünal ve 191 milletvekilinin verdiği 10/577 sayılı ve Halkların Demokratik Partisi (HDP) Bingöl Milletvekili İdris Baluken'in parti grubu adına verdiği 10/578 sayılı önergelerin TBMM Genel Kurulu tarafından 09 Nisan 2013'te kabulüyle oluşturulmuştur (http://tbmm.gov.tr/komisyon/cozum_sureci/docs/cozum_kom_raporu.pdf, s. 17).

8 Mayıs 2013 tarihinde çalışmalarına başlayan Komisyon, Anayasa'nın 98, TBMM iç tüzüğünün 104 ve 105. maddeleri ile ilgili diğer hükümlerine göre görev yapmıştır. Komisyon için tahsis edilen 3 aylık süre normalde 25 Ekim 2013'te dolmuş, ancak tatil ve ara vermeler sebebiyle iç tüzüğün 105. maddesi gereğince 1 aylık ek süre istenmiştir. Talep üzerine 24 Ekim 2013 tarih ve 1050 sayılı TBMM kararıyla bu süre verilmiş ve bu karar da 
26 Ekim 2013 tarih ve 28803 sayılı Resmi Gazete'de yayınlanmıştır (http://tbmm.gov.tr/komisyon/cozum_sureci/docs/cozum_kom_raporu.pdf, s. 19).

Komisyon, kendisine tahsis edilen yasal süreç içinde, çeşitli kurumların üst düzey bürokratlarının da katılımı, toplumun her kesitinden nitelikli kişilerin bilgisinden hareketle ve yerinden tespitlere göre hazırladığı, 12 bölüm ve 438 sayfadan oluşan raporu Kasım 2013'te TBMM'ye sunmuştur.

Bu raporun sonuç kısmının son paragrafı şu şekildedir: "Komisyonumuz Çözüm Sürecinin; Türkiye Cumhuriyeti topraklarmda yaşayan her birey için demokrasi, hukukun üstünlüğü, en gelişmiş haliyle insan haklarl, özgürlük, bin yıllık kardeşliğin devamı, barış içinde bir arada yaşama, diyalog, empati, karşılıklı anlayış ve hoşgörü zemininin oluşmasına, bu zeminin hukuki, idari ve siyasi gelişimle oluşan alt yapılarla desteklenmesine, oluşan bu çerçevede toplumsal barışımızın ekonomik, sosyal, kültürel dinamizm ve gelişmişlik düzeyimizin artış ile taçlanmasına ve en nihayetinde bütün bu kazanımların hissedilebilir ve sürdürülebilir bir niteliğe kavuşmasina hizmet ettiğine ve başarrya ulaşacağına olan inancını bu Rapor vesilesiyle Kamuoyuna saygıla arz etmektedir.(http://tbmm.gov.tr/komisyon/cozum_sureci/docs/cozum_kom_raporu.pdf, s. 431).

Yine çözüm süreci bağlamında 2013 yılı içinde Ak Parti tarafından geliştirilen bir başka önemli proje "Akil İnsanlar Heyeti/Komisyonu" oluşturulmasıdır. Birikimleriyle çözüm sürecine katkı sağlamaları amacıyla toplum tarafından tanınan ve içlerinde akademisyen, sanatçı, gazeteci, yazar ve sivil toplum kuruluşlarının temsilcilerindenoluşturulan 63 kişilik heyetin isimleri Başbakanlık tarafından 3 Nisan 2013'te kamuoyuna duyurulmuştur. 63 kişiden oluşan akil insanlar heyeti Türkiye'nin yedi coğrafî bölgesi baz alınarak dokuzar kişilik gruplara ayrılmıştır. Rifat Hisarcıklığlu, Can Paker, Tarhan Erdem, Yılmaz Ensaroğlu, Ahmet Taşgetiren, Deniz Ülke Arıboğan ve Yusuf Şevki Hakyemez bölge grubu başkanları olarak ilân edilmiştir. Akil insanlar heyeti ve dokuzar kişiden oluşan yedi bölgenin gruplarında yer alan isimlerin tam listeleri 3-4 Nisan 2013 tarihli gazetelerde yer almıştır.

Kurulduktan sonra kamuoyunda bir hayli yoğun tartışmalara sebep olan Akil İnsanlar Heyeti tarafından kurulan bölgesel grupların yaptıkları 
çalışmalardan sonra hazırlanan raporlar Başbakanlığa sunulmaya ve yayınlanmaya başlanmıştır.

Özellikle Doğu Anadolu ve Güneydoğu Heyetlerinin yaptıkları çalışmalardan sonra kamuoyuyla paylaştıkları bilgiler arasında konuyla ilgili önemli detaylar bulunmaktadır. Bu detaylardan birincisi, Akil İnsanlar Heyeti Doğu Anadolu Komisyonunun Kamu Düzeni ve Güvenliği Müsteşarlığı aracılığıyla Başbakan Recep Tayyip Erdoğan'a sunduğu ve 26 Haziran 2013'te yayınlanan raporda dile getirilen hususlardır.

Raporun, bir numaralı sosyal psikolojiye ilişkin öneriler ve talepler başlığı altında sıralanan maddelerin birinde: "Şeyh Said, Said Nursi, Seyyid Rıza vb. isimlerin itibarlarının iadesi"; dört numaralı kültürel öneriler ve talepler başlığı altındaki bir paragrafın sonunda da: "Iki pınar Şeyh Said ve Said Nursi. İade-i itibar olmalı" açıklamalarının yer almasıdır.

İkincisi ise Akil İnsanlar Komisyonu Güneydoğu Heyetinin iki aylık çalışma sonucunda hazırladı̆̆ı ve Başbakan Recep Tayyip Erdoğan'a sunduğu raporun bir bölümünde işaret ettikleridir. 26 Haziran 2013 tarihinde yayınlananbu raporun bir bölümünde, çözüm süreci hakkındaki görüş ve değerlendirmelerini almak amacıyla Mardin'de Hacı Abdülkadir Timurağaoğlu'nun ve yine Mardin'in dinî kanaat önderlerinden Şeyh Selahaddin Seydaoğlu'nun, Siirt'te de tarihî Tillo Medresesinin hocası Molla Burhaneddin Mücahidi'nin ziyaret edildiği belirtilmektedir (http://www.yeniturkiye.org/akil-insanlar-heyeti-guneydogu-raporu-aciklandi/yeni-turkiye/3652).

Her iki raporda da topluma mal olmuş, döneminin toplumsal yapısını iyi analiz etmiş dinî kanaat önderlerinin ve ileri gelen din âlimlerinin bölgede sahip oldukları etkinin ortaya konulmuş olması,o zaman için çözüm sürecinin bir ayağının nereye dayanması gerektiğinin ipuçlarını gözler önüne sermektedir.

Son olarak, Ak Parti'nin çözüm süreciyle alakalı ortaya koyduğu ve önemine binaen değinilmesi gereken bir başka projesi "Terörün Sona Erdirilmesi ve Toplumsal Bütünleşmenin Güçlendirilmesine Dair Kanun" adıyla çıkardığı yasadır. 6551 kanun numarasıyla 10 Temmuz 2014 tarihinde kabul edilen ve 11 Temmuz'da TBMM tarafindan Cumhurbaşkanının onayına gönderilen çözüm süreci ile ilgili kanun 15 Temmuz'da Cumhurbaşkanı Abdullah Gül tarafından onaylanarak "Terörün Sona Erdirilmesi ve Toplumsal Bütünleşmenin Güçlendirilmesine Dair 
Kanun" adiyla 16 Temmuz 2014 tarih ve 29062 sayılı Resmi Gazete'de yayınlanarak yasalaşmıştır.

Bu kanunla Ak Parti Hükümeti, çözüm süreci kapsamında terörün sona erdirilmesi ve toplumsal bütünleşmenin sağlanabilmesi için gerek yurtiçinde ve gerekse yurtdışında gerekli çalışmaları yürüteceğini taahhüt etmiştir. Ancak 11 Ağustos 2015 tarihi itibarıyla buzdolabına kaldırılan ve yukarıda önemli noktaları özetlenen çözüm süreci konusunda bugüne kadar olumlu/olumsuz pek çok gelişme yaşanmıştır. Süreç boyunca iktidardaki siyasi iradenin kararlı tutumuna rağmen, karşı tarafın verdiği sözleri ve vaat ettiği taahhütleri yerine getirmemesi bir samimiyetsizlik göstergesi ve çözümü sahiplenmeme, tabir caizse çözümsüzlükte hayatiyetini devam ettirme kolaylığına kaçma girişimi olarak karşımızda durmakta ve bu realite kamuoyu tarafından da dikkatle takip edilmektedir. Geriye dönüp bakıldığında ise çözüm süreci için harcanan maddi-manevibu kadar emekten ve zamandan sonra süreci akamete uğratanlarınzararda olduğu aşikârdır.

1 Kasım 2015 genel seçimlerinden sonra yeniden tek başına iktidara gelen Ak Parti, çözüm iradesini sürdüreceğini deklare etmiştir. Başbakan Ahmet Davutoğlu tarafından 25 Kasım 2015 tarihinde 64. hükümetin programı TBMM'de okunmuştur. Programda, hükümetin bir taraftan terörle kararlı bir şekilde mücadele edeceği, diğer taraftan da demokratikleşme ve çözüm iradesini sürdüreceği, demokratikleşme ile eş zamanlı olarak yatırım, üretim ve istihdam imkânlarının geliştirilmesi öncelikli olmak üzere, terörden etkilenen yörelerin ekonomik ve sosyal rehabilitesine yönelik çalışmaların hızlandırılarak devam ettirileceği vurgulanmaktadır. Ayrıca, "6551 Sayılı Terörün Sona Erdirilmesi ve Toplumsal Bütünleşmenin Güçlendirilmesine Dair Kanun" çerçevesinde toplumda kalıcı huzurun tesisi için silahın tamamen gündemden çıkarılması için gereken her türlü tedbirin alınacağı yer almaktadır (http://www.basbakanlik.gov.tr/docs/KurumsalHaberler/64.hukumet_programi. pdf, s. 22).

Ahmet Davutoğlu'nun Ak Parti Genel Başkanlığı'ndan istifasından sonra 22 Mayıs 2016'da düzenlenen olağanüstü kongrede Ak Parti Genel Başkanı seçilen ve yeni hükümeti kuran Başbakan Binali Yıldırım liderliğindeki yeni kabinenin hazırladığı hükümet programında da terörle mücadele konusunda aynı kararlılık vurgulanmıştır.Bu kararlılık 
hükümet programında şu şekilde dile getirilmiştir: "65'inci Hükûmet döneminde de hukukun üstünlüğ̈̈ne karşı tehditleri bertaraf etmek üzere, vatandaşlarımızın mağduriyetinin önlenmesi, can ve mal güvenliğinin sağlanması için terörle mücadele kararlılkla sürdürülecektir. Terörle mücadele amaçl devam eden operasyonlar; vatandaşlarımızın huzur ve güvenliği mutlak surette sağlanıncaya, sivil vatandaşlarımıza ve güvenlik güçlerimize yönelik silahlı saldırılar kalıcı bir şekilde sona erdirilinceye ve terör gruplarının silahları bıraktırlıncaya kadar kararlilıkla sürdürülecektir." (http://www.basbakanlik.gov.tr/docs/kurumsalhaberler/hprogram.pdf, s. 8).

Çözüm süreci konusunda Ak Parti iktidarları tarafından atılan adımlar hakkında bu bilgiler verildikten sonra, Said Nursi'nin hayatında önemli bir yeri olan Medresetü'z-Zehra projesinin öneminin irdelenmesine geçilebilir.

\section{Medresetü'z-Zehra Projesi Üzerinden Çözüm Sürecine Bir Bakış}

Said Nursi'nin hayat hikâyesine bakıldığında, onun yaşadığı dönemin toplumsal yapısını çok iyi gözlemleyen, toplumun talep ve beklentilerini iyi bilen, çok okuyan ve zeki bir din âlimi olarak tanındığı görülmektedir. Özellikle gençlik yıllarına denk gelen ve "Birinci ya da Eski Said Dönemi" olarak kabul edilen hayat kesitinde, yaşadığı coğrafyaya bakıp, cehalet içinde büyüyen, eğitimsiz genç neslin içine evrildiği karmaşık duruma baktıkça bir şeyler yapılması gerektiğini düşünmüştür. Çünkü gençler, içinde yaşadıkları toplumsal yapının kendilerine sunduğu kültürel kimlik aidiyeti üzerinden edindikleri sosyalleşmenin bir adım ötesine geçememekte, hazır buldukları devalarla ontolojik varlıklarını inşa edebilmelerinin getirisiyle inandıkları ancak realitede gelecekleri adına fayda sağlamayan doğrularıyla yaşamaya mecbur bırakılmışlardır.

Eğitim, insan hayatının her safhasında yer alan, insanı insan yapan faktörlerin en başında gelen ve nihai amacı da bireyin kendini gerçekleştirmesini sağlayan bir süreçtir (Erdem, Altunsaray; 2016, s. 23). Eğitimin böylesine önemli olduğuna inanan Said Nursi, dönemindeki Kürt gençlerinin eğitimden uzak bir şekilde yetişmelerinden endişe etmiş ve bu durumu değiştirmek için harekete geçmiştir. 
Said Nursi, bu durumu değiştirmek için bir proje geliştirmiş ve bu projenin hayata aktarılmasının peşine düşmüştür. Bu proje, Doğu Anadolu'da Mısır'daki Ezher Üniversitesi gibi eğitim verecek olan "Medresetü'z-Zehra" adlı bir İslâmî üniversitenin açılmasına çalışmaktır (Nursi; 2007, s. 54). Afrika kitasında yer alan Ezher Üniversitesi'ni İslâm âleminin mübarek ve umumî bir medresesi olarak değerlendiren, ayrıca burada öğrenim görmeyi çok arzu etmesine rağmen bunun kısmet olmadığını belirten Said Nursi, Asya kıtasının Afrika'dan daha büyük olması hasebiyle Medresetü'z-Zehra'nın da Ezher'den daha büyük bir İslâm Üniversitesi olarak Asya'da açılmasını istemiştir (Nursi;1997, s. 439). Şerif Mardin, Said Nursi'nin bu projesini, bir taraftan yalın bir öneri olarak değerlendirirken diğer taraftan da mutaassıp çizginin dışında kaldığına işaret etmekte ve henüz tanık olunmadık ölçüde modern bir renk taşıdığına dikkatleri çekmektedir (Mardin;2006, s. 62).

Said Nursi, Kürt çocuklarını eğitmek için "Medresetü'z-Zehra" adını verdiği ve Ezher Üniversitesi'nin kız kardeşi olarak nitelendirdiği bu üniversiteyi,nüfus bakımından yoğun olan Bitlis, Van ve Diyarbakır gibi illerde kurmayı düşünmüştür. Üniversitenin merkezi Bitlis olacaktı ve Bitlis'in iki tarafında yer alan Van ve Diyarbakır'da da iki şubesi açılacaktı. Nursi, bu düşüncesini ise şöyle dillendirmiştir: “Camiü'l-Ezher'in kız kardeşi olan, Medresetü'z-Zehrâ namıyla dârü'l-fünûnumutazammin pek âlî bir medresenin Bitlis'te ve iki refikastyla Bitlis'in iki cenahı olan Van ve Diyarbekir'de tesisini isteriz." (Nursi;1998, s. 126).

Nursi, ömrü boyunca bu projesini gerçekleştirmek için ilk ikisi Osmanlı ve son ikisi de Cumhuriyet döneminde olmak üzere toplam dört defa girişimde bulunmuştur. Bu konudaki ilk adımı, karış karış gezdiği Anadolu'nun ve sıkıntılarını yakından bildiği ahalinin durumunu padişaha arz etme düşüncesini hayata aktarmak (Şahiner;2008, s. 74; Iş1k;1995, s. 11; Yaşar;2008, s. 225) ve Doğu Anadolu'da bu üniversiteyi açtırmak için 1907 yılı Kasım ayının sonlarına doğru İstanbul'a gitmesiyle atmıştır (Sönmez, S. 86; Bahar;2004, s. 77; Işık;1995, s. 16; Yaşar;2008, s. 225; Şahiner;2008, s. 75).

Said Nursi'nin düşündüğü eğitim sisteminde dinî ilimlerle fen bilimlerinin beraber öğretilmesi vardı. Belirttiğimiz gibi toplumsal yapıyı çok iyi analiz eden Said Nursi'ye göre mektepli ve medreseli kavgasının altında da fen bilimleriyle din bilimlerinin beraber öğretilememesinden 
kaynaklanan sıkıntı yatmaktaydı. Tipkı ordudaki alaylı-mektepli çekişmesinin yarattı̆̆ sıkıntılar gibi. O zamanlar doğuda "Hamidiye Alayları" bulunmaktaydı ve bu alaylar yönetimde söz sahibiydi. 1891 yılında kurulan Hamidiye Alayları, geneli Kürt aşiretlerine bağlı olmakla beraber az sayıda Arap ve Türkmen aşiretlerinden olan bireylerden oluşmakta ve yarı askeri bir örgüt işlevi görmekteydi (Kutlay;2002, s. 62.) Said Nursi doğunun Hamidiye Alayları tarafından yönetilmesinden kaynaklanan eksiklikleri bilmekte ve bunların giderilmesinin yanısıra bilim, sanat ve fen noktasından da doğunun uyandırılması gerektiğine inanmaktaydı (Şahiner;2008, s. 81).

Nursi, Doğu'da beraber yaşayıp büyüdüğü bu insanların yeni tarz eğitim almaları gerektiğine inanmıştı. Bölge halkının çocukları Türkçe bilmedikleri için bu sebeple açlan okullara gidemiyorlardı. Dolayısıyla sadece dinî bilgiler veren medreselerde okuyup, oradan aldıkları bilgi ve icazetle yükselmeye çalışıyorlardı. Said Nursi, Sultan II. Abdülhamit'e verdiği dilekçede Bitlis, Van ve Siirt gibi yerlerde yeni okullar açılmasını, buralarda en az elli talebenin okutulması ve eğitim görecek bu çocukların bütün masraflarının devlet tarafından karşılanmasını ve dinî tedrisatın yanı sıra fen ilimlerinin de okutulmasını talep etmiştir. Böyle bir eğitim sisteminden geçerek yetişen yeni nesillerin Osmanlı'nın gelişmesine büyük bir katkı yapacağına ve cahillik içinde birbirleriyle çekişen ve birbirlerini tahrip etmek için didinen insanların medenileşeceğine inanmaktadır (Kösoğlu;1999, s. 48-49; Şahiner;2008, s. 83-84). Necmeddin Şahiner'in verdiği bilgilere göre, Said Nursi'nin Sultan II. Abdülhamit'e verdiği dilekçe "Şark ve Kürdistan Gazetesi"nin 19 Kasım 1908 tarihli nüshasında yayınlanmıştır. (Şahiner;2008, s. 84-85).

Bu dilekçenin bir bölümü günümüz Türkçesiyle şöyledir: "Doğu üniversitesinde okutulacak, dinîve fennî ilimlerle millî eğitimin temeli atıllır. Bu să̆lam temelden ise, birlik ve beraberlik binalar yükselir. Dahilî çekişmelerden dolayı vatanımızın kuvvetli bir parçası ve unsuru olan adı geçen beldelerin maddîmanevî kuvvetini hükümetin eline vermekle; harice sarf edilen bu kuvvet, vatan ve dinin yolunda kullanlacaktır. Bu kuvvet sahipleri fitrî kabiliyetlerini ve medeniyete olan istidatlarını da göstereceklerdir." (Şahiner;2008, s. 84-85).

Said Nursi'nin bu satırlarında açıç̧a görüldüğü gibi, her iki alana yönelik eğitimden geçen öğrenciler millî birlik ve beraberliğimizin teminatı 
olarak kabul edilmektedir. Çünkü ona göre vicdanların 1şığı olan din bilimleri ve aklın nuru olan fen bilimlerinin bir arada okutulmasıyla hakikat ortaya çıkmakta vedolayısıyla bu iki alan birbirlerinden ayrılmadan öğretilmelidir. Aksi takdirde din bilimlerinin ayrılmasıyla hile ve şüpheye, fen bilimlerinin ayrılmasıyla taassuba zemin hazırlanır. Said Nursi bu konuya dikkat çekerken şu ifadeyi kullanır: "Vicdânın ziyâsı, ulûm-u dîniyedir. Aklın nûru, fünûn-u medeniyedir. İkisinin imtizâccyla hakîkat tecellî eder. O iki cenah ile talebenin himmeti pervâz eder. Iftirak ettikleri vakit birincisinde taassup, ikincisinde hile, şüphe tevellüd eder." (Nursi;1998, s. 127; Kösoğlu;1999, s. 46). Mektep ya da medreseden aldıkları eğitimin verdiği "aidiyet psikolojisi" ile tatmin olmaya çalışan, "empatik düşünme yetisi" olmadığı için birbirlerini "biz" ve "öteki" şeklinde kategorik bir ayrıma, bir kamplaşmaya tabi tutanların ortak bir paydada buluşabilmeleri mümkün değildir.İşte bu yüzden İstanbul'a giden Said Nursi, padişahla görüşüp mekteplerde din dersleri, medreselerde ise müspet fen ilimleri okutulmasını teklif etmeyi amaçlamıştı. Onun düşüncesine göre, bu şekilde eğitim yapıldığı takdirde mektepliler dinsiz olmaktan, medreseliler de taassuptan kurtulacaklard1 (Şahiner;2008, s. 74). Said Nursi, Medresetü'z-Zehra projesi için yaptığı ilk başvuru sonucunda hüsrana uğramış ve bu başvuru sebebiyle kendisini önce tımarhanede, sonra da hapishanede bulmuştur (Şahiner;2008, s. 8595; Kösoğlu;1999, s. 50-54).

Said Nursi'nin Medresetü'z-Zehra hülyası için ikinci girişimi, 1911'de tekrar İstanbul'a gelmesi ve Sultan Reşad ile birlikte Rumeli gezisine çımasıyladır. Bu gezide Nursi, Sultan Reşad'a Medresetü'z-Zehra'nın önemini anlatır ve onuşu sözleriyle ikna etmiştir. "Cami-ül-Ezher, Afrika'da bir medrese-i umumiye olduğu gibi Asya Afrika'dan ne kadar büyükse, daha büyük bir Dar-ül Fünun, bir İslâm üniversitesi açılmak lazımdır. Ta ki İslâm kavimlerini, meselâ Arabistan, Hindistan, İran, Türkistan'daki milletleri menfì ırkçılık ifsad etmesin. Müsbet ve kudsi ve umumi milliyet-i hakikiye olan İslâmiyet ile bütün mü'minleri kardeş ilân eden Kur'an'ın bir kanun-u esasisinin tarz-ı intişarnna mazhar olsun ve felsefe fünunu ile ulum-u diniye birbiriyle barısssin ve Avrupa medeniyeti İslâmiyet hakikatleriyle tam musalaha etsin." (Nursi;1997, s. 280-281). Said Nursi "Medresetü'z-Zehra" nın yapımı için ikna ettiği padişahtan 20 bin altın lira almış, Van'a geri döner ve üniversitenin temelini atmıştır.Fakat Birinci Dünya Savaşı'nın başlamasıyla binanın inşasında bir ilerleme kaydedemez (Işık;1995, s. 17-18; Şahiner;2008, s. 147). 
Said Nursi'nin Medresetü'z-Zehra için üçüncü girişimi ise Cumhuriyetin ilânından hemen önce TBMM dönemine denk gelmiştir. Bilindiği gibi Nursi millî mücadeleye destek vermiş, İstanbul hükümetinin Kuvayı Milliye aleyhinde Şeyhülislâm Dürrizade Abdullah Efendi'den aldığı fetvaya karşı çıkmış, fetvayı yok hükmünde sayan ve fetvanın geri alınmasını isteyen açıklamalar yapmıştır (Kösoğlu;1999, s. 149; Işık;1995, s. 21; Şahiner;2008, s. 243).

Bu sebeple Ankara Hükümeti Reisi Mustafa Kemal olmak üzere dönemin önde gelenleri tarafından takdir edilmiştir. Said Nursi'nin vatan ve millete hizmetlerini yakından takip eden Mustafa KemalPaşa, onu Ankara'ya davet etmiştir. Nursi önceleri bu davete pek olumlu yaklaşmazsada sonunda daveti kabul etmiş ve 1922 yılında Ankara'ya gitmiştir (Kösoğlu;1999, s. 148; Işı;;1995, s. 21; Şahiner;2008, s. 246). İşte bu davet sebebiyle Ankara'ya gittiği zaman mecliste yaptığı konuşmada “Medresetü'zZehra"nın önemini anlatmıştır. Bu etkili konuşma sonrasında TBMM'deki mevcut 200 milletvekilinden 163'ünün imzasıyla bu üniversitenin inşası için 150 bin lira ödenek verilmesi kabul edilir (Nursi;2007, s. 140; Kösoğlu;1999, s. 150; Işı;;1995, s. 18).

Ancak kaynaklarda Medresetü'z-Zehra için tahsis edilen bu ödeneğin Said Nursi'ye verildiğine dair bir bilgi bulunmamaktadır. Said Nursi, Medresetü'z-Zehra için yaptığı bu üçüncü girişiminden de sonuç alamayınca kendisine teklif edilen makam ve mevkileri elinin tersiyle iterek Ankara'dan ayrılarak Van'a gitmiştir. Orada toplumsal hayattan uzaklaşmış bir halde Erek Dağı eteğinde Zernebad suyu başındaki küçük bir mağarada hayatını sürdürmeye başlamıştır (Nursi;2007, s. 144).

Said Nursi'nin Medresetü'z-Zehra için dördüncü ve son girişimi ise Demokrat Parti'nin iktidara gelmesiyle olmuştur. Tevfik İleri'nin Milli Eğitim Bakanı ve Celal Bayar'ın Cumhurbaşkanı olduğu dönemde yaptığı başvurunun kabul edildiği kendisine bildirilmiştir.Bayar tarafından Nursi'ye gönderilen yazıda, doğu vilayetlerinden biri olan Van'da böyle bir irfan müessesesinin kurulması için çalışmalar yapılacağı ve bütün sorunların halledilerek bir sonraki bütçe yılında işe başlanacağıifade edilmekteydi. Said Nursi, kendisine ulaşanbu müjdeli haberi talebeleriyle paylaşır. Ancak daha önceki girişimlerinde olduğu gibi bunda da bir netice alınamaz. Sonuçta Said Nursi'nin gerçekleştirmek için gece-gündüz 
çok çabaladığı ve özlemini duyduğu "Medresetü'z-Zehra" projesini somutlaştırmak ve meyvelerini devşirmek ona nasip olmaz (Işı; 1995, s. 18; Nursi;1997, s. 281).

Sıkça ifade edildiği gibi "Medresetü'z-Zehra" Said Nursi'nin bir hülyasıydı. Eski Said'in kendisini tamamen vakfettiği ve sonuç almak için her türlü çabayı gösterdiği, iki defa çok yaklaşmasına rağmen çıkan engeller yüzünden muvaffak olamadığı bir projeydi.Bu projeyi gerçekleştiremeyen Said Nursi, hapsedildiği zamanlar boyunca karşılaştı̆̆ı sıkıntıları manevi bir terbiye saymış ve hapishaneyi "Medrese-i Yusufiye" olarak isimlendirmiş ve bu isimlendirme takipçileri tarafından da benimsenmiştir.

Geçmişten ders alınmaması sebebiyle, var olan bir ihtiyacın tali sebepler yüzünden ötelenmesi ya da dikkate alınmamasının yarattığ 1 fiili durumdan doğan zararların tamamen telafi edilmesi mümkün olmamaktadır. Hatalardan dönmeyi bilmek, tarihi öğretinin düsturlaştırdığı üzere, erdemli bir harekettarzıdır.Bu sebeple toplumsal yapıyı çok iyi analiz etme yeteneğine sahip Said Nursi'nin bu projesiyle,eğer gerçekleşmiş olsaydı, o dönemde yaşayan Kürt gençleri din ve fen ilimleriyle harmanlanmış iyi bir eğitimden geçebilirlerdi. Dolayısıyla böyle bir tedrisattan geçerek büyüyen yeni nesillerden debaşkalarının maşası olarak kamu güvenliğini tehdit edecek "devlet düşmanı", "bölücü", "terörist" ya da benzer sıfatlarla tavsif edilen bireylerin çıkma ihtimalinin önüne geçilebilirdi. Sonuçta bugün PKK terör örgütünün beslendiği insan kaynağı olan eğitimsiz ve kandırılmaya müsait genç kitlelerin önü o zamandan kesilebilirdi.

Said Nursi'nin bir asır önce, bölge gençleri hakkında yaşadığı kaygı, bugün çeşitli kamu kuruluşları ya da sivil toplum örgütleri tarafından da açıkça dile getirilmektedir. Akil İnsanlar Heyeti'nin Doğu ve Güneydoğu Anadolu Heyetlerinin yeri geldikçe vurgulanan tespitlerinin yanı sıra bu durumun en bariz örneği yakın zamanlarda yaşanmıştır. Toplumu din konusunda aydınlatma göreviyle anayasal çerçevede ihdas edilmiş olan Diyanet İşleri Başkanlığı tarafından 17-19 Ağustos 2015 tarihleri arasında Ankara' da 31. İl Müftüleri İstişare Toplantısı düzenlenmiştir. Bu toplantı sonunda bir sonuç bildirgesi yayımlanmıştır. Kamuoyuyla paylaşılan bu sonuç bildirgesinin 10. maddesi aynen şu şekildedir: "Elleri kalem tutması, zihinleri ve gönülleri bilgiyle, ilimle, irfanla meşgul olması gereken çocuk yaştaki gençlerimizin İslam'ın özüyle ve ruhuyla asla bağdaşmayan bir inanç ve ideoloji ile dağlara kaçırılması, ellerine silah tutuşturulup ölüm makinası haline 
getirilmesi, kardeş katili yapılması, gayr-i meşru ve gayr-i insani bir hayata mahkûm edilmesi, insaf ve vicdan sahibi her yürek tarafindan tel'in edilecek bir durumdur." (http://www.diyanet.gov.tr/tr/icerik/il-muftuleri-toplantisisona-erdi/28081).

Yine Diyanet İşleri Başkanlığı tarafından uzun yıllar sonra Bakanlar Kurulu'na Türkiye'deki din hizmetleri konusunda ve özellikle de Doğu ve Güneydoğu Anadolu'daki gelişmeler çerçevesinde din hizmetlerinin daha etkin hale getirilmesi kapsamında yapılacak konular hakkında bir brifingverildiği 29 Şubat 2016 tarihinde kamuoyuyla paylaşılmıştır (http://dinihaberler.com/diyanet/diyanet-ten-bakanlar-kuruluna-brifingh89872.html).

$\mathrm{Bu}$ brifingin kapsamı hakkında açıklamalar yapan Diyanet İşleri Başkanı Mehmet Görmez, Bakanlar Kurulu'na bir dizi talep sunduklarını, bunlar arasında Doğu ve Güneydoğu'daki medreselerin önemine dikkat çektiklerini ve bu medreselerin legal hale getirilmesi gerektiğini deklare etmiştir (http://www.hurriyet.com.tr/diyanet-isleri-baskani-mehmetgormez-medreseler-legal-olmali-40065213).

Yukarıda aktarılan bilgilerden hareketle, Kürt geçlerini devlete kazandırmak adına Said Nursi'nin tesis etmek için yıllarca peşinden koştuğu "Medresetü'z-Zehra" projesinin öneminin bir kez daha gözler önüne serildiğini söylemek mümkündür.

\section{Said Nursi'nin Türk-Kürt Kardeşliğine Verdiği Değerve Önem}

Said Nursi'nin Türklere verdiği değer ve önemi, kendi eserlerindeki ifadelerde ve bu eserlerden hareketle ortaya konulan çalışmalarda görmek mümkündür.Dolayısıyla onun Türk-Kürt kardeşliğine verdiği değer ve önem bu çalışmalar üzerinden ortaya konulmaya çalışılmıştır.

Her şeyden önce şunu belirtmekte fayda vardır ki Said Nursi Kürt'tür ve Kürt olduğunusöylemekten hiçbir zaman kaçınmamıştır. Bazı eserlerine de Said-i Kürdî imzasını atmıştır.Ancak o hiçbir zaman Kürt milliyetçiliği yapmamıştır. Medresetü'z-Zehra projesini hayata aktarmak için Sultan II. Abdülhamit'e verdiği dilekçeden sonra çıkarıldığı Sıkıyönetim Mahkemesinde yargilanırken verdiği cevap bunun en açık delillerinden biridir. Mahkeme başkanı Şakir Paşa'nın: "Hangi Kürt aşiretine mensupsun?" şeklindeki sorusuna Said Nursi şu cevabı vermiştir: "Sen 
hangi Tatar aşiretine mensupsun? Ben Osmanlıyım, benim Kürtlüğ̈̈m doğup büyüdüğüm yerler itibarılladır." (Kösoğlu;1999, s. 50).

Said Nursi Kürt olmasına rağmen, hayatının çoğunu Türklerin içinde geçirmiş ve en yakın talebeleri, en sadık ve en halis kardeşleri hep Türklerden olmuştur. Bu gerçeği her fırsatta da dile getirmiş vebu duruma inanmayanlar için de Türk gençlerini şahit olarak göstermiştir. Açıkçası o, Türk-Kürt kardeşliğine verdiği değeri ve önemi her daim diline pelesenk etmiştir. Said Nursi bu gerçeği şu sözleriyle dile getirmiştir: "Ey efendiler! Ben, her şeyden evvel Müslüman'ım. Yüzde doksan dokuz menfaatli hizmetim Türklere olmuş ve en çok hayatım Türkler içinde geçmiş ve en sadık ve en halis kardeşlerim Türklerden çıkmış ve İslamiyet ordularının en kahramanı Türkler olduğundan, meslek-i Kur'aniyem cihetiyle, her milletten ziyade Türkleri seomek ve taraftar olmak, kudsi hizmetimin muktezast olduğundan; bana Kürt diyen ve kendini milliyetperver gösteren adamlarm bini kadar Türk milletine hizmet ettiğimi, hakiki ve civanmert bin Türk gençlerini işhad edebilirim." (Nursi;2007, s. 223-224.)

Onun Türklere verdiği değerin bir başka göstergesi de Kur'an'da geçen bir ayette zikredilen kavmin Türkler olduğunu eserlerinde açıkça belirtmesidir. Bu ayet Maide Suresi'nin 54. ayetidir ve anlamı şöyledir:"Ey iman edenler! Sizden her kim dininden dönerse, muhakkak Allah Teâlâ bir kavim getirir ki, onları sever, onlar da O'nu severler. Mü'minlere karşı mütevazi olurlar, kâfirlere karşı da izzet sahipleri bulunurlar. Allah yolunda savaşa atılırlar ve kınayanın kınamasından korkmazlar. İşte o, Allah Teâlâ'nın fazlıdır, onu dilediğine verir ve Allah Teâlâ vâsidir, alîmdir." (Bilmen;1990, s. 118).

Said Nursi bu ayetten hareketle düşüncelerini şu şekilde dile getirmiştir: "Allahu Zülcelal Hazretleri Kur'ân-ı Kerim'de 'Öyle bir kavim getireceğim ki, onlar Allah'ı severler. Allah da onları sever' diye buyurmuştur. Ben de bu beyân-ı İlâhî karşısında düşündüm. Bu kavmin bin yıldan beri âlem-i İslâm' ın bayraktarlığını yapan Türk milleti olduğunu anladım. Bu kahraman millete hizmet yerine dört yüzelli milyon hakikî Müslümanın kardeş bedeline, bir kaç akılsız kavmiyetçi kimsenin peşinden gitmem." (Mürsel;1976, s. 301; Şahiner;2008, s. 221; Kösoğlu;1999, s. 170-171).

Nursi, bu sözlerinde geçen dört yüzelli milyon rakamıyla kendi dönemindeki dünya Müslümanlarının toplam nüfusunu vermekte ve bir kaç akılsız kavmiyetçi ifadesinden de aslında Kürt milliyetçiliği yaparak devlete karşı isyan eden Kürtçüleri kastetmektedir. 
Said Nursi'nin Birinci Dünya Savaşı patlak verdiğinde, Kafkas Cephesinde kendisinin kurduğu Milis Teşkilatının kumandanı olarak Ruslar'a karşı savaştığı ve büyük kahramanlıklar gösterdiği bilinmektedir. Nursi'nin kurduğu bu milis gücü “Keçe Külahlılar” tabiriyle anılmakta, cephede en ön saflarda savaşmakta ve Ruslar arasında da büyük bir korku yaratmaktaydı. İşte bu yıllarda Kafkas Cephesinde çeşitli görevler üstlenen Aziz Samih savaş bittikten sonra hatıralarını yayınlamıştır. Yazdıklarının riyasız, yaldızsız hakikatler olduğunu ve özellikle buna itina ettiğini belirten Samih, hatıratında Said Nursi ile ilgili bir anekdot da aktarmaktadır. Savaş sırasında bölgede yaşayan ve dış mihrakların tuzağına düşen Ermeni ve Kürtlerin davranış tarzlarını ortaya koyması açısından önem taşıyan Samih'in sözleri aynen şöyledir: "Ermeniler alenen düşmanlıkların gösterdiler. Muharebenin daha başlangıcında kıt'alarındaki Ermeni neferler kaçtı. Düşman tarafina gittiler. Hattâ Ermeni doktorlardan bile kaçanlar oldu. Halbuki ordu, bunları kendi öz evlâdından ayırmamış, taburlarda onbaşı ve çavuşların epeycesi Ermenilerden nasbolunmuştu. Kürtler de gerek cehalet ve gerek teşvik neticesinde kaçıyorlar. Süvari kolordusunda ve 33 ve 34 . firkalarda bizzat gördüm ki hiç birisi gönülden harbe sokulmuyor, ilk firsatta kaçıyorlar. Bunların halini o sırada orduya nasihat için gelen Şeyh Saidi Kürdiye gösterdim. Dedi ki: Her şeyi söyledim. Fakat nasihat kâr etmiyor. Bu halleri gördükçe Kürt olduğuma utanıyorum. Arap efrat zaten harpcu değildir. Hele bu mıntakada soğuktan hareket iktidarları bile yok. Yine gayret ve fedakârlık arslan Türk efradına kalıyor." (Samih; 1934, s. 33).

Bu satırlar, Milis Kuvvetleri Kumandanı Said Nursi'nin, teşvik neticesinde ya da cehalet sebebiyle savaştan kaçan Kürtleri gördükçe Kürtlüğünden utandığını söyleyecek kadar mert olduğunu ve Türklere olan sevgisini ve inancını ortaya koymaktadır.

Türk-Kürt kardeşliğine verdiği önem ve değeri yukarıdaki söz ve davranışlarıyla açıkça ortaya koymaktan hiçbir zaman çekinmeyen Said Nursi, aynı gerekçelerle gerek Osmanlı döneminde ve gerekse cumhuriyetin ilanından hemen sonra vuku bulan Şeyh Said isyanına da destek vermemiştir.İsyancılara ve onları destekleyen Kürt aşiretlerine de yaptıklarının yanlış olduğunu söylemiş, onları gittikleri yoldan geri çevirmek için elinden gelen çabayı göstermiştir. Said Nursi, devlete karşı ayaklanmak isteyen isyancıları yaptıkları yanlıştan döndürmek için ilk çabayı, II. 
Meşrutiyet'in ilanından sonra Kürt aşiretleri arasında ortaya çıkan hoşnutsuzluğu ortadan kaldırmak için göstermiştir. 1910-1911 yıllarına denk gelen bu dönemde Said Nursi, isyan hazırlığındaki Kürt aşiretlerini dolaşarak II. Meşrutiyetin ilanıyla gelecek için iyi bir zemin oluştuğuna ve onları devlete olan bağlllıklarını sürdürme konusunda ikna etmeye çalışmıştır.

Cumhuriyetin ilanından hemen sonra Van'a giden ve kardeşi Abdülmecit'in evinde bir süre misafir olarak kaldıktan sonra Erek Dağı'na çıkan Said Nursi, izbe ve terkedilmiş bir kilisede bulduğu talebelerine iman ve Kur'an hakikatleriyle alakalı dersler vermeye başlamıştır.İşte onun bu dönemlerine tekabül eden zaman diliminde, Şeyh Said isyanına destek vermek ve ona katılmak isteyen on kadar Kürt aşiret reisi Said Nursi'ye gelip bu durumlarını anlatmışlardır.Nursi, buna şiddetle karşı çıkmış ve onlara dinimizde Müslümanların birlik ve beraberliklerini zedeleyecek ve harici düşmanlara karşı kuvvetlerini kıracak hiçbir dâhili isyana yer olmadığını izah etmeye çalışmıştır. Menfi milliyetçiliğin varlığımıza, birliğimizeve kardeşliğimize kastederek bu milleti parçalayacağını, bu gibi menfi hareketlere girişenlerin arkalarında ecnebi parmağı olmasından korktuğunu açıkça ifade etmiştir. Said Nursi ayrıca, bu milleti şimdiye kadar Türklerin idare ettiğini ve bundan sonra da onların idare edeceğini, idareye layık ve ehil olanların onlar olduğunu, eğer içlerinde kötü yola sapanlar varsa, gidip onları müspet manada ikaz etmeleri gerektiğini aşiret reislerine söylemiştir. Aşiret reisleri de Said Nursi'nin bu ikazları karşısında memnuniyetlerini dile getirmişler ve isyana iştirak etmekten vazgeçmişlerdir. Böylece Van isyana katılmamış, dolayısıyla pek çok masum insanın kanı dökülmemiştir (Yıldız;1992,s.238; Şahiner;2008, s. 268-269). Onun kişiliğini ve samimiyetini gösteren bu tavrı, hayatı boyunca uzak durduğu "menfi hareket etme" yerine, kendisine düstur edindiği ve talebelerine her zaman tavsiye ettiği "müspet hareket etme" felsefesinin bir yansımasıdır.

Said Nursi aynı ikazları Şeyh Said'e de yapmaktan çekinmemiştir.Bir Nakşibendî şeyhi olan Palulu Şeyh Said, şeyhliğini Mevlâna Halid'in halifelerinden Erbilli Ahmed'in dedesini Nakşibendî tarikatına kabul etmesi ve ondan kendisine intikal etmesiyle almıştır (Çay;1994, s. 400). Bir Nakşî şeyhi olarak itibar gören ve hükümete karşı ayaklanmayı planlayan Şeyh Said, nüfuzundan faydalanmak ve isyanına destek istemek için Said Nursi'ye bir mektup yazmıştır.Said Nursi ise yazdığı cevabî mektubunda kaleme aldığı şu satırlarla onu bu teşebbüsünden vazgeçirmeye çalışmıştır: 
"Türk milleti asırlardan beri İslâmiyet'in bayraktarlığını yapmıştır. Çok veliler yetiştirmiş ve çok şehitler vermiştir. Böyle bir milletin torunlarına kılıç çekilmez. Biz Müslümanız, onlarla kardeşiz, kardeşi kardeşe çarpıştıramayız. Bu şer'an caiz değildir. Kılıç, haricî düşmana karşı çekilir. Dâhilde kılıç kullanılmaz. Bu zamanda yegâne kurtuluş çaremiz, Kuran ve iman hakikatleriyle tenvir ve irşad etmektir. En büyük düşmanımız olan cehli izale etmektir. Teşebbüsünüzden vazgeçiniz.Zira akim kalır. Bir kaç cani yüzünden binlerce masum kadın ve erkekler telef olabilir." (Nursi;2007, s. 148; Y1ld1z;1992, s. 238; Şahiner;2008, s. 266; Kösoğlu;1999, s. 142-143).

Said Nursi'nin müspet hareket etme felsefesini iyi bilen ve onun tedrisatından geçen talebesi Mehmed Kırkıncı hatıratında, yukarıda aktardığımız tablo ile ilgili, Said Nursi'nin hayatı boyunca anarşinin karşısında yer aldığını, Şeyh Said olayında da isyanı engellemeye çalıştığını ve aynı zamanda doğudaki bütün aşiret reislerini isyana destek vermekten men ettiğini aktarmaktadır (Kırkıncı;2004, s. 93). Aynı gerçeği Şerif Mardin de dile getirmiş ve Said Nursi'nin bu ayaklanmanın elebaşlarıyla ilişki içinde olmakla suçlandığını, ancak Nursi'nin bu suçlamayı reddettiğini, tersine ayaklanmayı önlemeye çalıştı̆̆ını söylediğini aktarmaktadir (Mardin;2006, s. 157).

Şerif Mardin, yeni Türkiye Cumhuriyeti'ne karşı bir kalkışma hareketi olan Şeyh Said isyanını değerlendirirken şeyhlik makamının önderliği ile milliyetçiliğin birleşmiş halinin görüldüğünü belirtmektedir. Buna karşın Mardin, Said Nursi'nin kariyerini anlatırken, aşiret bağlılıklarının aşılarak daha geniş sınırlara sahip bağlılık birimlerinin oluşturulması yönünde bir pratiğe dönüştüğüne işaret etmektedir (Mardin;2006, s. 90). Mardin bu ifadeleriyle, Şeyh Said'in, şeyhlik makamını ve Kürt milliyetçiliğini arkasına alarak isyan ettiğini, bu isyana karşı çıkan Said Nursi'nin ise aşiret bağlarına dayanmadan daha geniş sınırları kapsayan İslam kardeşliği ve iman birliği idealinden hareket ettiğini belirtmektedir.

Said Nursi, Şeyh Said isyanı patlak verdiğinde yatıştırıcı rol oynamasına rağmen inzivada bulunduğu Van Erek Dağı'ndaki menzilinden alınarak isyana destek verdiği iddiasıyla sürgüne gönderilmiştir. Sürgünden Doğudaki nüfuzlu kimseler de nasiplerini almış ve Anadolu içlerine sürülmüşlerdir. Said Nursi Van'dan diğer sürgünlerle beraber karayoluyla önce Trabzon'a, oradan da deniz yoluyla İstanbul'a götürülmüştür. İstanbul'da yirmi gün kadar süren sorgulamalar boyunca Sirkeci'deki 
Arpacilar Mescidi ve Hidayet Camii'nde kalan Said Nursi, Ankara'dan gelen resmi bir yazı sonucu, zorunlu ikamete tabi tutulmak üzereönce İstanbul'dan İzmir'e, oradan da Antalya'ya ve nihayet 1925 yılının Mayıs ayının ortalarında Burdur'a getirilmiştir (Şahiner;2008, s. 269-274; Kösoğlu;1999, s. 171-172; Işı;1995, s. 13).

Türk-Kürt kardeşliğine verdiği değeri ve önemi dilinden düşürmeyen Said Nursi'nin bu şekilde başlayan sürgün hayat1,döneminin siyasi atmosferinden etkilenen idarecilerin kuşkuları sebebiyle aldıkları kararlar yüzünden, Türkiye'nin çeşitli yerlerinde mecburi ikametler halinde vefatına kadar sürmüştür.

\section{Dinî Bir Kanaat Önderi Olarak Said Nursi'nin Çözüm Süreci Açısından Önemi}

Terör meselesinin çözümü kapsamında yürütülen çözüm sürecinin temel dayanaklarından birinin iktidardaki Ak Parti tarafından oluşturulan "Akil İnsanlar Heyeti"olduğuna yukarıda değinilmişti. Bu heyet içinde yer alan Doğu Anadolu ve Güneydoğu Heyetlerinin yaptıkları çalışmalar sonucu elde edilen bilgilerden kamuoyuna yansiyanlardan hareketle, bölge halkının birer dinî kanaat önderi olarak gördükleri şahsiyetlere iade-i itibar istedikleri yayınlanan raporlarda görülmüş ve ismi geçen şahsiyetlerden birinin de Said Nursi olduğuyukarıda paylaşılmıştı.

$\mathrm{Bu}$ durum açıkça gösteriyor ki bölge halkı, geçmişte ve günümüzde kendileri için çalışan, topluma yol gösteren önemli şahsiyetlere itibar etmekte ve onları bir kadirşinaslık örneği olarak gönüllerinde yaşatmaktadır. Her ne sebeple olursa olsun, zaman içinde topluma mal olmuş bu insanların çektikleri sıkıntılar ve eziyetler paylaşılmış ve yeri gelince bu duygular dışarı vurularak gıyaplarında iade-i itibar istenmiştir.

Çözüm süreci kapsamında Akil İnsanlar Heyeti tarafından tespit edilen bu değerlendirmeler, Recep Tayyip Erdoğan tarafından çok daha önce dile getirilmiştir. Onun başbakanlığı döneminde, Ak Parti'nin 03 Ekim 2009'da düzenlediği 3. olağan kongresinde yaptığı konuşmada: "Seversiniz seomezseniz, beğenirsiniz beğenmezsiniz, görüşlerini kabul edersiniz etmezsiniz" sözleriyle başlayan ve "Ahmed-i Hani'nin yanı sıra Bitlisli Said Nursi'siz bir Türkiye'nin maneviyatı noksan kalır"diye biten sözlerini nasıl değerlendirmek gerekir? 
Said Nursi'ye başbakanlık makamı tarafından verilen değeri ve iade-i itibarı içeren bu ifadeler, yazılı ve görsel medyada bir hayli revaç bulmuştur. Özellikle Ak Parti'ye oy vermediği bilinen ve bunu açıkça ilân eden Yeni Asya Gazetesi yazarları bu sözleri sütunlarına taşımışlardır. Bu yazarlardan bir olan Cevher İlhan, bu vakıadan sonra Said Nursi'ye verilen iade-i itibar ve önemden ziyade, Said Nursi ismini en fazla zikreden başbakanın kim olduğunu tespit etmeye çalışmıştır. Bu konuda Mehmet Altan'ın 5 Ekim 2009 tarihli Star Gazetesinde; “Başbakan Tayyip Erdoğan, Adnan Menderes'den sonra Said-i Nursi adını resmen telaffuz eden ikinci başbakanmış" başlıklı yazısına, İlhan 7-8 Ekim 2009 tarihlerinde peşpeşe kaleme aldığı iki yazıyla cevap vermiş ve Mehmet Altan'ı eleştirmiştir. Yine bir başka Yeni Asya yazarı Kazım Güleçyüz ise Başbakan Recep Tayyip Erdoğan'ın sözleri üzerine 7 Ekim 2009'da kaleme aldığı "Bediüzzaman'ın Farkı" başlıklı yazısıyla düşüncelerini paylaşmıştır.

İade-i itibar konusu sadece Said Nursi'nin kendisiyle sınırlı kalmamıştır. Nursi hayatı boyunca yargılanırken kendisiyle beraber eserleri de yargllanmış ve zaman zaman eserleri de mahkum edilmiştir. Bu sebeple 26 Kasım 2014 tarihli ve 29187 sayılı Resmi Gazete'de yayımlanan Bakanlar Kurulu kararıyla Bediüzzaman Said Nursi'ye ait eserler üzerindeki 5846 sayılı Fikir ve Sanat Eserleri Kanunu'ndan kaynaklanan tüm haklar ve yetkilerin Diyanet İşleri Başkanlığına devredilmesi, aynı zamanda bu eserlerin devletleştirilmesi anlamına gelmektedir.

Yine yukarıda değinildiği üzere Diyanet İşleri Başkanlığı tarafından yapılan İl Müftüleri İstişare Toplantısınınsonuç bildirgesinin 11. maddesi,tıpkı Doğu ve Güneydoğu Anadolu Akil İnsanlar Heyetlerinin tespitleri gibi, toplumun kanaat önderlerinin yüklendikleri misyonun önemine işaret etmiştir. Söz konusu madde şu şekildedir: "Ülkemizin en zor zamanlarında, din eğitiminin yasaklandiğı dönemlerde bölgede İslâm'ın ilim, hikmet ve marifetini ayakta tutabilmek için gayret gösteren, irşat hizmetlerini sürdüren, halkımızın Din-i Mübin-i İslâm'la, Kur'an ve Sünnetle ilişkisini sıcak tutan kanaat önderleri ile birlikte barış, huzur, sükun tesis edilmesi için müşterek çalışmalar yapılmalıdır. Unutulmamalıdır ki; barışa sadece ülkemizin ve milletimizin değil, umutlarmı bu ülkeye ve bu millete bağlayan tüm mă̆dur ve mazlumların ihtiyacr vardır." (http://www.diyanet.gov.tr/tr/icerik/il-muftuleri-toplantisi-sona-erdi/28081). 
Türkiye'nin toplumsal yapısını oluşturan ve onu ayakta tutan sosyal unsurların başında İslâmî değerler gelmekte ve bu değerlerle yoğrulan gelenekselleşmiş kültürel miras, milli ve manevi değerler nesilden nesile aktarılmaktadır. Kuşkusuz İslâm, Anadolu coğrafyasının en saf, en yalın gerçeklerinden biridir. Türkler bu toprakları yurt edinmeye başladığından beri İslam'ın gerçek anlamıyla barış, adalet, kardeşlik vb. ilkelerinden hareketle bir medeniyet oluşturmaya çalışmıştır. Bu sebepledir ki Anadolu İslâm yorumu yapılırken, Hoca Ahmed Yesevi, Yunus Emre, Mevlana Celâleddin-i Rumi ve Hacı Bektaş-1Veligibi bu topraklar için manevi önder olmuş pek çok gönül insanının hikmet ve bilgeliği her daim zikredilir ve kardeşlik bağları bunlar üzerinden kuvvetlendirilir. Tarihe bir imza olarak atılan Çanakkale'nin geçilmez olduğunun ve millî mücadelenin destansı başarısının arkasında işte bu ruhun gayreti ve birlikteliği vardır. Bu gerçeklikten hareketle muhafazakâr bir nüfus yapısına sahip olan Doğu ve Güneydoğu Anadolu Bölgelerinde yaşayan Kürt nüfusun çoğunluğunun, Marksist-Leninist bir felsefe temeli üzerine kurulmuş olan PKK terör örgütüne zoraki şartlar dışında cevaz vermeyeceği apaçık bir hakikattir. Dolayısıyla dönemlerini iyi tahlil etmiş ve topluma mal olmuş Said Nursi vb. kanaat önderlerinin yaşadıkları zaman sürecinde bölge halkına aşıladıkları milli ve manevi birliği sağlayıcı mesajların yabana atılmaması gerekir. Çünkü zamanında gerçek yönüyle değerlendirilip anlaşılamayan bu tarihî birikimden ders çıkartılması ve gelecek için aynı hataya düşülmemesi, Türkiye için kangrenleşen terör meselesinin çözümünde uygulanabilecek en önemli alternatif stratejilerden biridir.

\section{Sonuç}

Terör meselesi kurulduğundan beri Türkiye'nin güvenlik açısından karşılaştığ1 en önemli sorunların başında gelmektedir. Bu sorun bağlamında PKK terör örgütü ve türevleri tarafından sürdürülen terör olayları neticesinde, Türkiye ciddi anlamda mal, can ve zaman kaybına uğramıştır. Bu meselenin çözümü için geçmiş siyasal iktidarlar tarafından genelde geçici tedbirlerle çözüm üretilmeye çalışılmış, ancak fazla bir yol alınamamıştır. Soruna salt bir güvenlik meselesi olarak bakmak ve de facto tedbirlerle çözüm bulmaya çalışmak yanıltıcı olmuştur. Güvenlik 
kaygısıyla beraber toplumsal, kültürel, siyasal ve ekonomik alanlarda zamanın gerektirdiği tedbirleri almak, terörün en azından yurt içindeki beslenme alanlarını, dayanaklarını ve kaynaklarını kurutmak açısından önem taşımaktadır.

Bu açılardan bakıldığında, Ak Parti iktidarları tarafından milli birlik ve beraberliği pekiştirmek adına "çözüm süreci" adıyla meselenin çözümüne yönelik her alanda yapılan uygulamalar, seleflerinin aksine toplumsal hafızada kendisine daha fazla yer bulmuştur. Ne var ki 7 Haziran seçimlerinden sonra oluşan siyasi konjonktürden faydalanmak isteyen taraflar eliyle başlatılan terör olayları yüzünden süreç, Cumhurbaşkanı Recep Tayyip Erdoğan'ın söylemleri doğrultusunda buzdolabına kaldırılmıştır. Silahların tamamen susması ve PKK terör örgütü mensuplarının hepsinin Türkiye'yi terk etmesi şartına bağlanan yeni dönemde, devletin terörle mücadelede geri adım atmayacağının ipuçları verilmiş, milli birlik ve kardeşlik için bölge halkının teröristlerle ve terör üzerinden beslenenlerle kendi arasına kalın çizgiler çekmesi gerektiğinin altı çizilmiştir. Buradan çıkan sonuç açıktır. Bölge halkının silahların sustuğu dönemde katedilen mesafeye bakarak, terör olaylarının başlamasıyla yaşadığı durumu analiz edebilecek bir tecrübeye, mukayese ve muhasebe yapabilecek bir kapasiteye sahip olduğu ortadadır. Bu tecrübenin bir sonucu olarak, son günlerde bölge halkının desteğiyle terörle mücadele konusunda sağlanan başarılar gelecek adına umutları yeşertmektedir.

Çözüm süreci kapsamında oluşturulan Akil İnsanlar Heyetinin Doğu ve Güneydoğu Anadolu temsilcilerinin tespitleri de bölge halkının özellikle toplumsal hafızaya mal olmuş şahsiyetlere verdiği değeri ortaya koymuştur. Her ne sebeple olursa olsun, anayasada belirtilen sinırları çiğnemeyen, toplumun değer verdiği şahsiyetler üzerinden geçmişte yaşanan sıkıntıların bugünlerde telafi edilmesi, geleceğin sağlam temellere dayandırılması için atılması gereken bir adımdır. Bir ülkenin tarihinde karanlık sayfaların olması ve bu sayfalara erişimin yasaklanması, hâlihazırdaki ve gelecekteki nesillerin hakikatin bilgisine ulaşmalarına ipotek konulmasıyla eşdeğer bir durumdur. Zamanında devleti idare edenlerin kendi doğrularıla eziyet ettikleri toplumun kanaat önderlerine yaptıkları hakkaniyete uymayan muamelelerin deşifre olmaması artık yaşadığımız teknoloji çağında mümkün değildir. Bu yüzden gelecek nesillerin dimağlarını malul tarih bilgisiyle doldurma dönemi, günümüzde 
hükmü kalmamış bir uygulamadan ibarettir. Tarihin ruhunun olduğu, her bilgiye ulaşmanın küresel bir realite haline geldiği bir dönemde hiçbir sırrın ilelebet baki kalmayacağı ve ifşa olacağı aşikârdır.

Dinî bir kanaat önderi ve bir Kürt olan Said Nursi de milli birlik ve kardeşlik projesinin pekiştirilmesi için gereken toplumsal dinamiklerden birisi olarak karşımızda durmaktadır. Muhafazakâr Kürtler için ona verilen değer, iade-i itibar talebiyle zaten deşifre edilmiştir.Said Nursi'nin hayatı boyunca bir felsefe, bir yaşam tarzı haline getirdiği mücadelesi ve mirası, onun toplumsal bir manevi kanaat önderi olarak kabul edildiğini göstermektedir.Kürt gençlerini ve daha sonra gelecek nesilleri devlete kazandırmak adına Medresetü'z-Zehra projesini hayata aktarmak için harcadığı çaba takdire şayandır.Ayrıca Diyanet İşleri Başkanlığı'nın Bakanlar Kurulu'na 29 Şubat 2016'da sunduğu brifingte Doğu ve Güneydoğudaki medreselerin legal hale getirilmesinin talep edilmesi Said Nursi'nin bu çabasında ne kadar haklı olduğunun bir başka göstergesidir.Sık sık belirtildiği gibi Nursi, yaşadığı sıkıntılı hayata rağmen hiçbir zaman devlet düşmanlığı yapmamış, hayatını müspet hareket etme felsefesi üzerine temellendirmiş ve bu felsefeyi talebelerine de vasiyet etmiştir. Onu daha da önemlikılan bir başka özelliği de Türk-Kürt kardeşliğine verdiği değeri üstüne basa basa vurgulaması veMaide Suresi'nin 54. ayetinde geçen kavmin de Türkler olduğunu açkça söylemesidir.Bütün bunlar Said Nursi'nin terör meselesinin çözümü için yürütülen milli birlik ve kardeşlik projesi kapsamında bir rol model olarak sunulabileceğinin ayrı ayrı birer göstergesidir.

\section{KAYNAKÇA:}

Çay, A. M. (1994), Her Yönüyle Kürt Dosyası, Turan Kültür Vakfı Yay., İstanbul.

Bilmen, Ö., N,,(1990), Kur'ân-ı Kerîm ve Türkçe Meâli Âlisi, Bilmen Yay., Ankara.

Erdem, A., R. ve Altunsaray, M.,(2016), “Eğitimde Niteliği Belirleyen Önemli Bir Etken: Eğitim Etiği", Akademik Sosyal Araştırmalar Dergisi, Y11: 4, Say1: 23. 
-http://www.akparti.org.tr/site/akparti/parti-programił\#bolum.Erişim Tarihi: 22 Nisan 2015.

-https://www.akparti.org.tr/site/haberler/milli-birlik-ve-kardelik-projesi-

kitapc/47710\#1,Erişim Tarihi: 29 Nisan 2015.

-http://www.basbakanlik.gov.tr/docs/KurumsalHaberler/64.hukumet_pro-

grami.pdf, s. 22, Erişim Tarihi: 26 Kasım 2015.

- http://www.basbakanlik.gov.tr/docs/kurumsalhaberler/hprogram.pdf, s. 8,

Erişim Tarihi: 26 Haziran 2016.

-http://dinihaberler.com/diyanet/diyanet-ten-bakanlar-kuruluna-brifing-

h89872.html.

-http://www.diyanet.gov.tr/tr/icerik/il-muftuleri-toplantisi-sona-erdi/28081,

Erişim Tarihi: 24 Ağustos 2015.

-http://www.hurriyet.com.tr/gundem/23594851.asp, Erişim Tarihi: 05 Mayıs 2015.

- http://www.hurriyet.com.tr/diyanet-isleri-baskani-mehmet-gormez-medreselerlegal-olmali-40065213.

-http://www.resmigazete.gov.tr/eskiler/2014/07/20140716-1.htm, Erişim Tarihi: 06 Mayıs 2015.

-http://www.sabah.com.tr/gundem/2015/07/22/2-polis-sehit-edildi. Erişim Tarihi: 22 Eylül 2015.

-https://www.tbmm.gov.tr/hukumetler/KP57.htm, Erişim Tarihi: 15.03.2016.

-http://tbmm.gov.tr/komisyon/cozum_sureci/docs/cozum_kom_raporu.pdf,

04.05.2015.

-http://www.turkiyegazetesi.com.tr/politika/296110.aspx. Erişim Tarihi: 22 Eylül 2015.

-http://www.yeniturkiye.org/akil-insanlar-heyeti-guneydogu-raporu-aci-

klandilyeni-turkiye/3652, Erişim Tarihi: 05 Mayıs 2015.

Işık, İ.,(1995), Bediüzzaman Said Nursi ve Nurculuk, Beyan Yay., İstanbul.

Kırkıncı, M.(2004), Hayatım-Hatıralarım, Zafer Yay., İstanbul.

Kösoğlu, N.(1999), Bediüzzaman Said Nursî Hayatı - Yolu - Eseri,

ÖtükenNeş., İstanbul.

Kutlay, N.,(2002), 21. Yüzyıla Girerken Kürtler, Pêrî Yay., İstanbul.

Mardin, Ş. (2006), Türkiye'de Din ve Toplumsal Değişme Bediüzzaman Said

Nursi Olayı, Çev.; Metin Çulhaoğlu, İletişim Yay., İstanbul.

- Milliyet Gazetesi, 17 Aralık 1999.

-Milliyet Gazetesi, 12 Ağustos 2005. 
Mürsel, S.,(1976), Bediüzzaman Said Nursi ve Devlet Felsefesi, Yeni Asya Yay., İstanbul.

Nursi, B. S.,(2007),Tarihçe-i Hayatı, Yeni Asya Neşr., İstanbul.

Nursi, B. S. (1997), Emirdağ Lâhikası, Yeni Asya Neşr., İstanbul.

Nursi, B. S. (1998), Münâzârât, Yeni Asya Neşr., İstanbul.

Özervarli, M. S.,(1997) "HÂNÎ, Şeyh Ahmed", İslâm Ansiklopedisi, TDV Yay., C. 16, İstanbul.

Sabah Gazetesi, 12 Ağustos 2005.

Samih, A. (1934), Büyük Harpte Kafkas Cephesi Hatıraları, Büyük Erkânıharbiye Matbaası, Ankara.

Sönmez, S. (2004), “Bediüzzaman Said Nursi'nin İlk İstanbul Hayatına Dair Bazı Belgeler", Köprü Dergisi, S. 86, İstanbul Bahar.

Star Gazetesi, 5 Ekim 2009.

Şahiner, N.,(2008), Bilinmeyen Taraflarıla Bediüzzaman Said Nursî, Nesil Yay., İstanbul.

Yaşar, İ. (2008), Zamanın Sesi, Yeni Asya Neşr., İstanbul.

-Yeni Asya Gazetesi (Muhtelif Sayılar).

-Yıldız, Z. (1992), Kürt Gerçeği "Olaylar, Oyunlar, Çözümler", Yeni Asya Yay., İstanbul. 


\section{Kaynakça Bilgisi / Citation Information}

Arslan, H. (2016). Farklı bir perspektiften terörizm, OPUS - Uluslararası Toplum Araştırmaları Dergisi, 6(11), s.491-520. 